\title{
The Multiple Personalities of Daniel J. Boorstin: A Third Image Analysis
}

Michael E. Meagher, University of Missouri, Rolla

This article presents a new interpretation of Boorstin's political thought. I contend that there are three Daniel J. Boorstins, and that the third image represents the core of Boorstin's political thought. The third image centers on Boorstin's insistence that an essence guides and directs American politics and thought. Boorstin terms his version of essence "givenness." According to Boorstin, essence, or "givenness, "was assigned to America by a Supreme Being. While Louis Hartz bases his concept of "irrational Lockeanism" in the thought of a social contract theorist. Daniel Boorstin bases his notion in the essence of God.

Daniel J. Boorstin is often overlooked as a political thinker. Yet there are many reasons for studying his political thought, not the least of which is his grand theory of American life and politics. Boorstin is convinced, like Louis Hartz, that there is an essential substance to American life. Hartz explained American political development in terms of a monolithic American philosophy he termed "irrational Lockeanism." According to Hartz, John Locke has acquired a stranglehold on American life, limiting its development, preventing the appearance of competing philosophies, and at times resulting in a neurotic style of behavior (e.g., the so-called "Red Scare").

Boorstin shares Hartz's belief in an essential substance to American life, but in contrast to Hartz Boorstin bases his version of substance on a more abstract, even mystical foundation. Boorstin labels his version of irrational Lockeanism "givenness." In America, values are "given;" that is, accepted without hesitation. But whereas Hartz grounded his notion in the thought of an English philosopher, John Locke, Boorstin ties his concept to God. The difference is significant, for Boorstin's thought metaphysically ascends to a Supreme Being, while Hartz remains tied to a social contract theorist.

Yet this interpretation of Boorstin's thought remains clouded. In no small measure, this is due to the nature of the Boorstin enterprise, for scholars must confront the fact that there are several Daniel J. Boorstins. The political thought of Daniel $\mathbf{J}$. Boorstin is a case of multiple personalities. Just as John Patrick Diggins has identified two Daniel J. Boorstins

Michael E. MEagher is Assistant Professor of Political Science at the University of Missouri, Rolla.

The American Review of Politics, Vol. 15, Winter, 1994: 461-480

Q1994 The American Review of Politics 
(Diggins 1971a), ' it is possible to identify three Daniel J. Boorstins. On the one hand, Boorstin celebrates American pragmatism and its rejection of ideological constructs. Boorstin is viewed as an anti-theoretical historian; as one who values non-ideology above all else. ${ }^{2}$ This, then, is the first image of Daniel J. Boorstin: the anti-theoretical Boorstin. The first image is the interpretation of Boorstin most frequently stressed by the literature. ${ }^{3}$

However, John Patrick Diggins shattered the image of the antitheoretical Boorstin. Diggins suggested that Boorstin, despite his antagonism toward theory, had produced a European type of philosophy. Diggins identified the paradox of Boorstin's thought: "Boorstin is a philosopher of history in spite of himself, and the ideas with which he demonstrates the absence of ideas in American history are as rich and as abstract as the European philosophies he finds so repugnant" (Diggins 1971a, 101). Boorstin, Diggins argued, was a closet Hegelian. The historian opposed to political theory, but who nonetheless produced a political theory, is the second Daniel J. Boorstin. The second image of Boorstin, therefore, may be called the philosophical Boorstin. Despite seeing Boorstin's work in philosophical terms, Diggins retained an affinity with earlier interpretations in at least one respect: Diggins ignored Boorstin's insistence that an essence, or essential substance, characterizes American politics and thought. ${ }^{4}$ According to Diggins, "eternal becoming," not a fixed substance or essence, dominates Boorstin's political writings. Boorstin, he argues, transforms American history into "process" by transforming the is into the ought (Diggins 1971a, 1971b). Thus, Diggins' philosophical Boorstin emphasizes existence, or constant change and experience. As used in this paper, therefore, existence refers to constant change and flux. It deals with the influence of the American frontier.

This essay, however, offers a different interpretation. I contend that in Boorstin's thought an essence (which comes from God) guides the direction of American politics. Throughout this analysis, the terms essence, essential substance, givenness, genius, and core of values will be used interchangeably. But the meaning of these various terms will be constant and steady. This essence acts as a moderating (or restraining) influence. I therefore will argue that Daniel Boorstin's political thought subordinates existence to essence, with the implication being that a tradition, or core of values, shapes existence. Far from conceptualizing history in terms of process alone, Boorstin's writings present history as being shaped by an essence that transcends and guides the direction of American politics. This is what Boorstin means by the "genius" of American politics. His "genius" of American politics transcends, guides, and shapes American institutions, politics, and thought. Boorstin suggests that "givenness," his version of essence, is the defining 
characteristic of American thought. "By this I mean what the Romans might have described as the tutelary spirit assigned to our nation at its birth and presiding over its destiny" (Boorstin 1953, 1). This means, then, that there is another Daniel J. Boorstin: the Essence Boorstin (the third image). Although A.J. Beitzinger associated essence with Boorstin many years ago, scholars have not focused on Beitzinger's observation. Indeed, Beitzinger's comments were restricted to a couple of paragraphs, and thus did not even begin to explore this very important topic (Beitzinger n.d.). This third image of Boorstin, which has been ignored by the literature, will be the subject of this analysis.

The third personality of Daniel J. Boorstin demonstrates how different Boorstin's thought is from that of Louis Hartz. The two simply are not the same; they do not offer variations on the same theme. Hartz laments America's "irrational Lockeanism," while Boorstin celebrates America's essence (or givenness). In Hartz's view, "irrational Lockeanism" destroys philosophy, and thereby limits America's potential. In Boorstin's perspective, however, givenness creates new possibilities, and transforms America from a dull repetition of Europe into a new, dynamic "land of dreams-come-true" (Boorstin 1953, 171). Only by adopting the third interpretation of Boorstin's thought can this essential difference between Hartz and Boorstin be clarified. Accordingly, I will show that Boorstin and Hartz are oceans apart: while Hartz sees Lockeanism as imprisoning America in chains, Boorstin conceives of givenness as removing the chains, and allowing America to reach its full potential.

Although it may appear that Hartz and Boorstin offer similar accounts of American thought, their theoretical ideas are grounded in different concepts. The liberalism of Louis Hartz ("irrational Lockeanism") is not another version of essence. To Hartz, American liberalism was derived from John Locke. To Daniel Boorstin, however, "givenness" (i.e., essence) comes directly from God (Boorstin 1953, 1992). This identification of essence with God is a consistent element of Boorstin's thought. He first made the connection in The Genius of American Politics, and reiterated the relationship in his most recent publication, The Creators.

\section{American Politics and Its Genius: The Guiding Force of Givenness}

As defined by Boorstin, "givenness" possesses three central characteristics: (1) values come from the past, or the "preformation ideal;" (2) values come from the landscape; and (3) the continuity of American history and politics. There is, as will be discussed, an inherent tension in these components of his definition, for Boorstin combines essence with existence. 
First, Boorstin describes American history in terms of a "preformation ideal." He argues that the values of America come from the past. These values, he says, have been present from the very beginning. "We believe that the mature political ideals of the nation existed clearly conceived in the minds of our patriarchs" (Boorstin 1953, 10). American values did not have to be discovered, for from the moment the Puritans landed at Massachusetts Bay a normative ideal already was shaping the theocratic Puritans. "Who could have predicted," Boorstin asks, "that Puritans would become Yankees?" $(1965,3)$. The fact that a normative ideal was shaping the development of American political institutions, society, and thought meant that "the values and theory of the nation were given once and for all in the very beginning" (Boorstin 1953, 11).

Boorstin labels this aspect of givenness the "preformation ideal." He describes this element in biological terms. The preformation ideal is the belief "that if you could look at the seed of an apple under a strong enough microscope you would see in it a minute apple tree." This, in turn, leads Boorstin to assert that if scholars can "understand the ideas of the earliest settlers - the Pilgrim Fathers or Founding Fathers-we would find in them no mere seventeenth or eighteenth century philosophy of government but the perfect embryo of the theory by which we now live" (Boorstin 1953, 10). Boorstin uses the analogy of an "exoskeleton" to highlight the preformation ideal, for he contends that God provided the foundation for American life. "Our theory of society is thus conceived as a kind of "exoskeleton," says Boorstin, "like the shell of the lobster" (Boorstin 1953, 16). This outer shell, provided by God, is the framework within which American history has unfolded. "We think of ourselves as growing into our skeleton, filling it out with the experience and resources of recent ages. But we always suppose that the outlines were rigidly drawn in the beginning" (Boorstin $1953,16)$. Although the Puritans based their society on God, their vision of life was contrary to America's essence. The Puritans insisted on conformity and became dogmatic in their behavior. To use Boorstin's analogy of the "exoskeleton," the Puritans wanted to create a solid object without an interior. They wanted to transform the outer shell of God into the solid mass of God. But a transformation of an "exoskeleton" into a solid mass requires specificity, for the Puritans tried to define American life; their early efforts to establish a theocracy did not accept the "givenness" of American values. To the Puritan settlers, values did not seem apparent; instead, they had to be defined.

But the central characteristic of American givenness is its undogmatic character. Religion in America (as will be shown) has been non-denominational and non-confrontational. American churches have accepted the 
givenness of American values, and have not tried to define or articulate a theology. When the Puritans sought to develop a theocracy, America's essence forced them to moderate their efforts, resulting in the inclusion of the Puritans in the American core of values. Boorstin's God, therefore, rejects dogmatism, and asks Americans to accept His values without hesitation or without an explicit definition of those values.

American values, thus, come from God, and are continually influencing the direction of American politics. Since God provided the nation's moral code, the preformation ideal assumes that European philosophy is irrelevant to American circumstances. Boorstin challenges the notion that the American Founding has a connection to the Enlightenment. "[T]o deny that a European Enlightenment authored American Thinking in the eighteenth century is simply to say, after all, that Shakespeare himself wrote Shakespeare" (Boorstin 1960, 65-66). In his view, American intellectual historians have found it convenient to think in grand terms. That is, it is relatively easy to associate the American Founding with developments in Europe, and to argue that the "American Enlightenment" was simply an extension of the European Enlightenment. Scholars who look to European thought distort American history, Boorstin suggests. According to Boorstin:

It is flattering to think that we were born in the bright light of Reason. It is also academically very convenient: we can grasp the thought of our philosophically inarticulate Founding Fathers by simply letting the European philosophes speak for them (Boorstin 1960, 65).

He added that "The notion of an American Enlightenment can best be described as a set of highly sophisticated oversimplications" $(1960,66)$. The American Revolution and the Founding, Boorstin argues, were unique events that can only be understood by recognizing the influence of givenness on American values and institutions (1960).

Because American thought is not European in derivation, the United States has been spared from ideology. Ideology, Boorstin contends, is made unnecessary by the influence of the preformation ideal. European political parties, he suggests, must cling to ideology; for Europeans, given their lack of a preformation ideal, have engaged in political theorizing.

In the last century or so, whenever citizens of continental western Europe have found themselves in desperate circumstances, they have had to choose among political parties, each of which was committed to a particular theoretical foundation for its whole program-'monarchist,' 'liberal,' 'catholic,' 'socialist,' 'fascist,' or 'communist' (Boorstin 1953, 20). 
But whenever Americans find themselves in desperate situations, theyunlike Europeans-have a supreme confidence that values and concepts are already known. Whereas the Europeans feel insecure when faced with crisis, Boorstin argues that the American essence, or givenness, provides guidance for American history and politics. "Confident that the wisdom of the Founding Fathers somehow provided for all future emergencies, we have not felt bound to limit our experiences to those which we could justify with theories in advance" (Boorstin 1953, 20).

Second, Boorstin identifies the "landscape" as defining American values. It is on this point that many, including Diggins (1971a, 1971b), confuse existence with essence. Without question, this is an especially beguiling point, something that Boorstin himself admits. "This second face of 'givenness'," writes Boorstin, "is at once much simpler and much more vague than the concept of preformation" (Boorstin 1953, 23).

Whereas the preformation ideal is "ideal and static in its emphasis, "the influence of the landscape is "practical and dynamic" (1953, 23). In this regard, he is attempting to balance a fixed and stable component, the preformation ideal, with an active and energetic factor. "Preformation means that the theory of community was given, once and for all, in the beginning; the second sense of givenness means that the theory of community is perpetually being given and ever anew" (Boorstin 1953, 23). Thus, both the past and the present affirm a fixed essence for America. American values are, in short, both a gift of the past and a fact of contemporary life. "The American," he writes, ". . . is equipped with a hierarchy of values, a political theory" (1953, 23). This, in turn, means that "Both axioms together encourage us to think that we need not invent a political theory because we already possess one" (Boorstin 1953, 23). With this second postulate of givenness, Americans possess a comprehensive explanation-one encompassing both stability, or the preformation ideal, and change, or the influence of the landscape (Boorstin 1953, 23). But the landscape does not produce values. Rather, the landscape reaffirms the values that were given at the nation's founding.

And, finally, Boorstin completes his definition of givenness with the assertion that American history is characterized by "continuity." In many ways, this third aspect of the definition flows naturally from the first and second components, for since values were present from and affirmed in the very beginning and are reaffirmed by the landscape of American life, American history must be an uninterrupted linear process. Indeed, Boorstin himself has characterized the continuity of American history as "a kind of link between the two axioms which I have already described" (Boorstin 1953, 30). 
This belief that there has been an essential continuity in American history and politics leads Boorstin to view the American Revolution as a conservative occurrence, and the American Civil War as a footnote. "The American Revolution was in a very special way conceived as both a vindication of the British past and an affirmation of an American future" (Boorstin 1953, 94-95). And the American Civil War did not produce epic political thought, he asserts, because the givenness of American values made any effort at theorizing unnecessary. "The fact that the conflict was along sectional lines, that each side purported to be fighting in defense of elaborate institutions and way of life, made any elaborate philosophizing on the subject seem superfluous, " according to Boorstin $(1953,103)$. In order to draw out the implications of these assertions, I will first discuss Boorstin's interpretation of the American Revolution, and then turn to consider his view of the American Civil War.

The Revolution, according to Boorstin, must not be viewed as an extension of the tumults then occurring in Europe. Indeed, the American Revolution was a "conservative" revolution, which simply sought to affirm the values given by the landscape. In The Genius of American Politics, Boorstin argued that:

The more familiar type of colonial revolution-like that which recently occurred in India-is one in which a subject people vindicates its local culture against foreign rulers. But the American Revolution had very little of this character. On the contrary, ours was one of the few conservative colonial rebellions of modern times (Boorstin $1953,70)$.

In The Americans: The National Experience, Boorstin argues that the American Revolution was an assertion of givenness. Americans reacted against European methods and thought. The essence of America (i.e., givenness) would not allow alien ideas to be transplanted. When the attempt was made, however, the essence of America sprang into force. The Revolution "was another way of seceding from European ways of thinking, another dissolving of Old World absolutes" (Boorstin 1965, 393).

The "Old World absolutes" concerned the British attempt to apply a theory of sovereignty to American practice. The British, Boorstin argues, were influenced by European theorists such as Jean Bodin and Thomas Hobbes. The British saw the Parliament in London as the expression of sovereignty. Sovereignty, the British felt, could not be divided into smaller units. Political systems, thus, must be centralized. But such a viewpoint, which Boorstin castigates as dogmatic and absolutist, did not fit American circumstances, for the American colonists already had developed a system of federalism (Boorstin 1965). 
From the early 17th century. while American experience was creating a working federal framework, European thinkers were busy asserting that such an arrangement was inconceivable or inconsistent with the existence of a modern state (Boorstin 1965. 396).

The slowness of communications, and the geographic distance between Britain and her colonies, had conspired to produce an American federalism. Royal authority was slow to be extended across the Atlantic. Reports and communications between London and the colonial governments necessarily were delayed. In these circumstances an arrangement developed whereby American colonial legislatures assumed responsibilities for internal matters, including taxation, while the Parliament in London managed imperial policy relating to trade, defense, and foreign policy. American federalism, Boorstin writes, already was an established fact before the Revolution. The colonial legislatures, despite the assertions of European theorists, did share sovereignty with the British Parliament (Boorstin 1965). What sparked the Revolution was the British Parliament's insistence upon applying European theories of sovereignty to American practice. Such an application was inappropriate to American conditions, and led to the Revolutionary War. "This was not the first nor the last time European thought would prove inadequate to American realities," Boorstin observed (1965, 397).

The Revolution demonstrates an essential continuity in American history, according to Boorstin. The Revolution was a by-product of the Glorious Revolution of 1688. "To many thoughtful colonists the War for Independence seemed but a logical sequel to British history of the previous century and a half" (Boorstin 1965, 404). He added that, "From a British Whig point of view, it was a second civil war, a fight to extend and localize in America the principles of the Glorious Revolution of 1689" (Boorstin 1965 , 404). Thus, the Revolution was a continuation of the British Revolution of the previous century. But in Boorstin's view this continuity did not end with the Revolutionary War. The "secession" of the American colonies from the British Empire (in the name of local liberties) re-occurred in the mid-nineteenth century. The American Revolution "provided the basis for a secessionist tradition which shook the new nation in the 19th century" (Boorstin 1965, 404). This meant that "[t]he struggle for a new nation was not to be completed until 1865 or after" (Boorstin 1965, 404). ${ }^{5}$

The Civil War produced no political theory. This is a central tenet of Boorstin's thought. According to Boorstin, "Sociology was actually playing the role of political theory" in the intellectual debate $(1953,106)$. Americans did not speculate, or develop elaborate normative models. Instead, they concentrated on the empirical, or as Boorstin would say, "the conflict was to be waged on an empirical rather than a metaphysical battlefield" (1953, 
103). In both the North and the South the givenness of American values seemed readily apparent, he contends. Despite the turmoil created by the Civil War, and the great controversy of slavery, scholars felt no need, as they might have in Europe, to engage in metaphysics. Instead, they turned to sociology. Even Southerners such as George Fitzhugh turned to sociology. "In a variety of ways the most respectable intellectuals of the South tried to make the facts speak for themselves" (Boorstin 1953, 108). He added:

But their preoccupation was with the facts: the connection between slavery and everything else that went on in the South; to the relation of labor to the accumulation of capital, to leisure. religion, literature, science, and the position of women (Boorstin, $1953,108)$.

Boorstin reduces Northern thought during the same period to a sociological basis. Despite the fact that "On the northern side it was perhaps easier to be absolutist and abstract, " this did not happen $(1953,111)$. Northern scholars, like their Southern counterparts, engaged in sociological analysis. "[T]he politically effective northern opposition to slavery was actually of a different character. It was, in fact, based less on love for the Negro than on concern for the white workingman" (Boorstin 1953, 111). Northern spokespersons were concerned about the possible negative impact of slavery on wage levels in the North, and the resultant competitive pressures.

There is a contradiction between Boorstin's argument in The Genius of American Politics (his major work) and his later argument in The Americans: The National Experience. In his earlier work, Boorstin contended that the slavery controversy did not produce any political theory. But in The Americans: The National Experience he describes the pre-civil war debate as "the Great Age of American Political Theory." The South produced an absolute, "unwritten" law, according to Boorstin. This unwritten law, Boorstin continues, was not only absolute but changeless. It was, in fact, dogmatic and inflexible. "Like the Quakers before them, the Southerners would not tolerate any compromises for fear all would be lost, "Boorstin has written. "As the Quakers lived by an unwritten theology, so Southerners too lived by an unwritten civil law; both were rigid and unbending" (Boorstin 1965 , 206). Southern politicians, he argued, rejected compromise. The political leadership of the South was dedicated to an abstract principle; the South, or, alternatively, the Southern way of life. As such, the politicians of the South engaged in "metaphysical politics" (Boorstin 1965, 218). Southerners were committed to the fixed and unchanging "unwritten law" of the South. "Southern apologists increasingly championed not specific projects nor a complex region," says Boorstin, "but an abstract cause: The South" 
(Boorstin 1965, 218). Given that the political hierarchy engaged in "metaphysical politics," the logical implication is that political theory would be more relevant. Boorstin makes this argument, for during this "great age, Southerners rivaled the philosophical works of Europe.

\footnotetext{
This was the Great Age of American Political Theory, and the South produced virtually the only American works of political theory to rank with those of the Old World. Was it so surprising that a people who had come to live by the changeless absolutes of unwritten law proved so adept at abstracting the essences of political thought? (Boorstin $1965,218)$.
}

Yet, Boorstin implies that this "great age" was an exception, not the norm. Perhaps it was an effort to break away from "givenness, " for "[t]his trilogy of political theoreticians is without match in all American history" (Boorstin 1965, 218). Clearly, then, Boorstin has not discarded his concept of givenness. Although in The Americans he asserts, contrary to his earlier argument, that Southerners did produce political theory (that, in fact, theirs was the "great age" of American Political Thought), Boorstin nonetheless claims that this was an aberration, not a normal occurrence in American history. Givenness, therefore, forced the Southerners to return to the American norm.

Daniel J. Boorstin's concept of "givenness" has been identified as having three explicit characteristics: (1) first, the preformation ideal; (2) second, the landscape of America; and finally (3) the continuity of American history. As the discussion has demonstrated, his writings argue that an essence guides American history and politics. This essence, although reaffirmed by the "landscape" (i.e., existence) of contemporary America, nevertheless guides American history toward a goal or condition. In Boorstin's thought, the environment (i.e., existence) does not completely shape essence. On the contrary, essence, or givenness, shapes and influences existence. An essential substance or essence is at the center of Boorstin's notion of givenness. American history is not a continuous process of eternal becoming. Change and constant fluctuation in American institutions, morality, and values are not the norms. On the contrary, Boorstin argues that a basic stability characterizes American life. The values of America are stable, and this normative stability guides the direction of American history. A "genius, " therefore, characterizes American life. This "genius" is an essence that maintains American institutions, politics, and thought, on a constant course. American givenness, Boorstin contends, comes directly from God. 
history and on our ground. This is what I have called the sense of givenness (Boorstin $1953,161)$.

In a later work, The Creators, Boorstin directly associates essence with God. The West's belief in a "Creator-God," according to Boorstin, had the most significant implications for man himself. Boorstin asserts that the characteristics of the "Creator-God" were transmitted to man. "The great Unnameable [i.e., God] had made men resemble Him" (Boorstin 1992, 41). This transmission of God's characteristics to man occurred through Moses and Saint Augustine (Boorstin 1992).

Boorstin describes how God appeared to Moses, and thereby became relevant to man's life. But while appearing to Moses, God simultaneously retained a distance from man, a fact that Boorstin labels "[t]he contradictory characteristics of this Creator-God." The God of Moses was not to be named. To speak the name of God ("I AM THAT I AM," or "Yahweh") was not permitted in the Jewish faith (Boorstin 1992, 40). Moses, in fact, refused to look directly at the burning bush. Yet, Boorstin attaches great significance to these "contradictory characteristics," for God assigned some of this mystery to man himself. God, according to Boorstin, had told Moses "Certainly I will be with thee," implying that God and His traits would be with man. "For while the God was not to be seen or even to be named, He entered intimately into every man's life and treated man as a kind of equal" (Boorstin 1992, 40). The reciprocal relationship between the Creator-God and mankind was codified in the Covenant, with "God's ambassador, Moses, sealing the covenant with the children of Israel" (Boorstin 1992, 42). The ties between man and God brought about by the social contract between God and man created "a new intimacy between God and man," according to Boorstin $(1992,41)$. In fact, "[t]he perpetual covenant between a CreatorGod and a Man-in-God's-Image was an extraordinary idea, " Boorstin asserts $(1992,42)$.

\footnotetext{
For man's awareness of his capacity to create, the Covenant was a landmark. It declared that a people become a community through their belief in a Creator and His Creation. They confirmed their creative powers through their kinship, their sharing qualities of God, their intimate and voluntary relationship to a Creator-God (Boorstin $1992,42)$.
}

Saint Augustine completed the process of transmitting God-like traits to man. Augustine produced a new conception of history, according to Boorstin. This new view of history assigned a crucial role to man as a creator. Augustine challenged the classical cyclical theory of history. In its place, Boorstin writes, Saint Augustine developed a "philosophy of history" in which the creator-man produces events that have never occurred before. "In 
a historic coup d'etat men had seized the powers of their Creator," says Boorstin $(1992,63)$. This means that "[e]very event is unique, and every soul follows its own destiny, to survive in Hell or Heaven." Man's abilities as a creator meant that "[n]o one could know when fulfillment would come, for History was a continuous unfolding of man's mysterious capacities-for creation, for love of God, for joining the Eternal City" (Boorstin 1992, 63). With Saint Augustine the process started by Moses had been partially completed; man had assumed the God-like ability to create. In doing so, an essence was assigned to man. In America, the potentialities of man's Godlike essence would be completely and finally realized (Boorstin 1975). "[T]he idea that novelty was possible and might be good had appeared even before Darwin. But its popularization, its laboratory demonstration, waited upon the American experience," Boorstin contends $(1975,20)$.

In order to more fully address the issue of how essence shapes existence it will be necessary to direct attention toward Boorstin's interpretation of American religious thought. This analysis will include a discussion of how religion generally is accepted in American life (an acceptance that does not produce conflict). However, underlying the entire analysis will be the implications of essence (i.e, givenness) for Boorstin's political thought.

\section{Religion as a Reflection of Givenness}

Because the values of America come from God it is only natural that religion should serve as a reflection of the sense of givenness. In America, Boorstin contends, there is a basic consensus about religion. Despite the large number of religious denominations, religion serves as a unifying force in American life. Americans, he asserts, do not argue about the merits of differing theological perspectives. Instead, Americans find solace in the nation's "non-denominationalism."

Boorstin defines "non-denominationalism" as a generalized religion. In America, despite its denominational diversity, there is an essential unity to religion. This is reflected in the "interfaith" organizations which unite Protestant, Roman Catholic, and Judaic faiths in common purposes. American holidays, he continues, "have this non-denominational, yet distinctly religious, character" (Boorstin 1953, 146). Thanksgiving, he says, "has no significance if not religious" $(1953,146)$. This is true of other holidays as well, including Christmas, Easter, and Memorial Day. Even political actions in America are typically framed in this non-demoninationalism. "A non-denominational ritualism accompanies the sessions of Congress and state legislatures and the inaugurations of presidents and governors," Boorstin points out $(1953,146)$. Non-denominationalism, he contends, is 
characterized by a vague and undeveloped religious philosophy. According to Boorstin:

\footnotetext{
This generalized religion is itself virtually without dogma. It is as far as possible from anything like pantheism, or even from anything as un-dogmatic as humanism. What it is, is the lowest common denominator of all presently accepted and respectable religions found within the borders of our country (Boorstin 1953, 147).
}

The fact that so many different religious groups can coexist peacefully within the same community is an extraordinary thing. In Boorstin's view this coexistence is directly attributable to the influence of givenness. American values are given; they are accepted without hesitation. In America this means that religion can be discussed without creating dangerous disruptions. It also means that religion can be discussed without developing theological justification because the values of American religion already appear to be given. Boorstin is particularly impressed with the "tendency to talk about, or perhaps more precisely to 'brag' about, what we believe, without troubling with technicalities like definitions" $(1953,149)$. He adds that "[p]erhaps never before in history has a people talked so much and said so little about its basic beliefs" (Boorstin 1953, 150).

This ability to discuss religion without creating disruptions is due to the lack of emphasis placed upon theology. Americans have not developed elaborate theological systems. Just as the United States has not produced political philosophy, it has quite similarly neglected theology. Theologians such as Reinhold Niebuhr, Boorstin contends, have been few and far between $(1953,152)$. The reason for not developing a complicated theology is that "[t]here is already so much agreement" (Boorstin 1953, 140). "The same reason why we have produced very little speculative political theory is why we have not been concerned with basic doctrinal issues in religion" (Boorstin 1953, 140).

Because so little emphasis has been placed on theology, churchsupported colleges, Boorstin points out, have risen above narrow denominationalism. American church-supported schools have avoided the danger of theological extremism. Despite their religious background, church supported schools have not become theologically dogmatic. "[T] he odium theologicum was not a prevalent disease in America" (Boorstin 1965, 155). The "generalized" religion of America, therefore, found expression in the nation's church-supported colleges. "The survival needs of sectarian colleges became potent and lasting influences toward the vague religiosity of American life" (Boorstin 1965, 154). This "vague" religiosity, Boorstin continues, led many observers to label American religion "Nothingarianism." "To make their colleges appeal to everybody, to people who believed anything or nothing, 
the denominations themselves became powerful breeders of "Nothingarianism, ' which observers said was the truly dominant American sect" (Boorstin $1965,154)$. "Nothingarianism" reflected the influence of "givenness," for church supported schools, Boorstin contends, moved away from their strict religious heritage. They moved, that is, in the direction of a "generalized" American religion. "That denominationally founded colleges might rise above their origins was already demonstrated in such older eastern institutions as Harvard, Yale, Dartmouth, Amherst, and Williams," Boorstin suggested $(1965,154)$.

Given that there is a "generalized religion" in America, political rhetoric tends to become blended with religious concepts. American political leaders constantly refer to religious themes. Quite similarly, religious leaders include political rhetoric in their comments. American "sermon[s] should have some worthy social implication," notes Boorstin $(1953,159)$. They are able to do so because there is a general agreement on the nature of religion in America. This is what Boorstin means by the "mingling of political and religious thought."

The more popular and influential preachers of our national ideals have stood midway between politics and religion: Franklin, Washington, Jefferson, Lincoln, Bryan, Theodore Roosevelt, Wilson, and even Franklin D. Roosevelt (Boorstin 1953, 159)

Religion, therefore, is a reflection of givenness. The fact that religion in the United States is "generalized"-that this "generalized" religion provides the basis for a "mingling" of political and religious rhetoric-is directly attributable to the influence of givenness (i.e., essence). American values do not have to be discovered. By the same token, American life is shaped by a "genius" (an essence or givenness) that maintains the trajectory of American history. American history is, thus, continuous, for the "genius of American politics" maintains the nation's direction. As described by Boorstin, American religion demonstrates the sustaining power of this "genius."

\section{Implications: A Comparison with Louis Hartz}

This essay has identified three Daniel J. Boorstins. The first Boorstin (the anti-theoretical Boorstin) is the image typically emphasized by the literature. This is the Boorstin who is avowedly opposed to political theory. Yett, despite Boorstin's apparently anti-theoretical posture, John Patrick Diggins identified another Daniel J. Boorstin: one who, despite his stated opposition to political theory, had produced a European type of philosophy. This Boorstin has been labeled the philosophical Boorstin (or, alternatively, the second 
image). This essay has built upon, but also departs from, Diggins's interpretation. Diggins sees the philosophical Boorstin as one emphasizing constant change and "eternal becoming." Accordingly, this analysis has identified a third Daniel J. Boorstin, and has delineated this third image. This third image is the essence Boorstin; a scholar who, as Diggins argued, has produced a European style political theory. But the essence Boorstin, in contrast to the philosophical Boorstin, emphasizes an essential substance and stability in American politics. American history is not characterized by constant change and flux, Boorstin argues. Rather, a "genius" characterizes American politics, according to Boorstin, and this "genius" is the notion of givenness, a notion which Boorstin argues comes directly from God.

There is a paradox to the third image (the essence Boorstin) that can be described best with reference to Louis Hartz. Hartz's interpretation of American politics centers on an "irrational Lockeanism" that has acquired a stranglehold on American political development. Americans cannot understand foreign nations, according to Hartz, because they are confined to a Lockean world. The liberalism of John Locke has destroyed American philosophy. 6 "[T]he psychic heritage of a nation 'born equal' is . . . a colossal liberal absolutism, the death by atrophy of the philosophic impulse," according to Hartz $(1955,285)$.

The significance of the third image of Daniel $\mathrm{J}$. Boorstin is that Boorstin celebrates what Hartz had lamented. Boorstin and Hartz often are seen as "consensus" historians (Diggins 1988, Fowler 1991, Lutz 1992). ${ }^{7}$ But the third image of Daniel J. Boorstin shows that Boorstin and Hartz offer vastly different conceptions of American political thought. ${ }^{8}$ In Boorstin's view, "givenness" gave to America a morality-indeed, a philosophy-for all time and circumstances. Far from limiting America, as Hartz argued, "givenness" (or essence) established the framework within which new possibilities and potentialities could become reality. Whereas Louis Hartz, according to Diggins, felt "sorrow" regarding America's "irrational Lockeanism" (Diggins 1988), Boorstin felt joy about America's sense of "givenness."

This joy is due to the fact that America's essence made the impossible become reality. Without givenness, without an essence, America would have been limited. But givenness actually opened new doors, and new avenues of development for the Americans (Boorstin 1953, 1975). "[T] he whole American experience," says Boorstin, "has been utopian" (1953, 174). Essence, according to Boorstin, made America into "the land of dreams-come-true" $(1953,171)$. America showed the world that the new and unique was a possibility. Europe, prior to the American experience, was the land of the "discoverer." But discovery is not innovation: "Its primary meaning is to 
uncover, or to disclose to view" (Boorstin 1975, 6). America, in contrast, because of its essence is the land of the "explorer." And, unlike the more limited "discoverer," the "explorer" opens up new avenues that have never occurred before. "[T]he explorer is one who surprises (and so makes people cry out) or one who makes new knowledge flow out" (Boorstin 1975, 6). "The discoverer simply uncovers, but the explorer is one who opens" (Boorstin 1975, 6). This dichotomy is at the center of the Boorstin enterprise. The "discoverer" characterized Western thought until America produced the "explorer." America's contribution to Western thought is the spirit of new ideas. And these new ideas are made possible by the American sense of "givenness."

Boorstin's "explorer" is an earlier version of his notion of "creator," for the explorer establishes new knowledge just as the creators "create" new ideas and things. In The Creators, Boorstin described how God transmitted some of his traits to mankind, thereby assigning an essence. Since America is the land of the "explorer" as "creator," essence is an American characteristic. In The Exploring Spirit, Boorstin made clear that essence was finally realized in America. The Americans, therefore, embraced the creative (i.e., God-like) spirit, and downplayed the role of the "discoverer." By downplaying the role of the "discoverer" in American thought, Boorstin is downgrading the importance of his argument in The Discoverers, for Boorstin makes clear his preference for essence. Yet, the "Creator," not the "Discoverer," is the realm of essence.

Boorstin's preference for the "Creator" over the "Discoverer" has implications regarding whether Boorstin actually believes in essence. It could be argued that Boorstin asserts that the Americans believed they had an essence, but that Boorstin himself does not share that point of view-that is, he recognizes, without subscribing to, the Americans' perception of an essence. Yet, by downgrading the discoverer and elevating the creator (explorer), Boorstin makes clear his belief that essence is at the heart of American life. By assigning God-like traits to man and actualizing those traits in America, Boorstin's position is evident: essence is real, and not just perceived.

Boorstin's positive feelings about the impact of essence on American life are due to his association of essence with God. Boorstin contends that there is a morality to American history, and that this morality came directly from a Supreme Being. As Boorstin observed in The Creators, the traits of God were assigned to man. By transferring some of His traits to the Americans, God transformed givenness into a liberating device. Instead of confining America, as Hartz's Lockeanism tries to do, Boorstin's essence, by 
encapsulating God around the Americans, gave to them the ability to be innovators.

Europeans, without an essence, had produced political theory. But this production of political theory was a sign of desperation or, more bluntly, a sign of the limitations of Europe. While Hartz admires the European ability to produce political theory, Boorstin believes that political theory has imposed severe restraints on Europe. Political theory is needed in Europe because they do not possess a sense of "givenness, " according to Boorstin. In America, new political theory is not needed because a God-inspired essence (i.e., political theory or givenness) already exists. Europe is limited by its constant production of political theory, while America is liberated by its possession of an essence.

\section{The Multiple Personalities Theme}

I have described the political thought of Daniel Boorstin as possessing three images: the anti-theoretical, the philosophical, and the essence. In this analysis I have stressed a previously under-emphasized interpretation of Boorstin's thought, the third image. I have concluded that essence represents the central core of Boorstin's thought, and that essence is the idea behind the concept of "givenness." In Boorstin's thought, essence is derived from God, who furnished the nation with a moral and political theory at the nation's origin. By examining the third image of Daniel Boorstin it has been possible to differentiate Boorstin's thought from that of Louis Hartz, whose "irrational Lockeanism" is based on the thought of an English philosopher, while Boorstin's "givenness" is rooted in the essence of a Supreme Being.

There are a number of implications to be drawn from the multiple personalities theme. Probably the most apparent concerns the relationship between the three images. Developing a third image of Daniel Boorstin does not mean that the other two images are without utility. Certainly, the antitheoretical Boorstin is a part of the puzzle, for he is critical of ideological interpretations of American history and politics. By the same token, the philosophical Boorstin is a relevant part of the explanation. Boorstin does write in a theoretical fashion, as Diggins argued, but there is more to Boorstin's theoretical posture than the "process" and Hegelianism that Diggins identified. In many ways, the first two personalities deal with the image of Americans-as-pragmatic adapters that is a part of Boorstin's thought. Still, the first two images do not address the role of essence that is also a part of his political thought. Boorstin does identify God as the source of American values. God provided the Americans with a moral code, and this standard has guided American history and politics from the days of the Puritans. 
Given that the first two images are relevant parts of the Boorstin puzzle, and that essence (the third image) is similarly crucial to Boorstin's political theory, one is left with the conclusion that the three images fit together.

The multiple personalities thesis asserts, however, that the three images fit together with the third image occupying the major role. Boorstin himself identified the role played by essence in his writings when he compared givenness to an "exoskeleton" (Boorstin 1953, 16). Essence provides the framework; the structure for American life. Within the value code handed down from God, Americans are able to engage in process and pragmatic adaptation. But essence is always present. It is there acting as a system regulator, modifying, changing, and shaping behavior. Essence ensures equilibrium and balance. Therefore, certain behaviors, certain actions expose the hand of essence, meaning that essence can, and, according to Boorstin, does shape American history, life and politics. The Europeans constantly must produce political theory because they lack an "exoskeleton" to provide them with stability. Without an essence the Europeans are all process, for they go from one extreme to another, in a constant search for an essential substance. Clearly, then, by performing the role of "exoskeleton," essence limits the need for ideology, for if an essence designed by God is handed down from generation to generation there is no need for a new or competing theory. Quite similarly, if there is no need to ponder definitional or theoretical questions, then Americans can engage in pragmatic activity. They can adapt, and engage in innovation. But, the important consideration to keep in mind is that this would not be possible without essence. Without an essence, the Americans would have been condemned, as the Europeans were, to a "process" moving from one extreme to the next.

\section{NOTES}

${ }^{1}$ The two Boorstins identified by Diggins are the historian and the philosopher. "[O]ne senses that there are two Daniel Boorstins-the articulate historian and the philosopher who prefers to keep his premises "inarticulate"" (Diggins 1971a: 100). Marian Morton (1972) identifies a philosophical side to Daniel Boorstin. According to Morton, the early Boorstin based his political thought on the writings of Blackstone, especially the trinity of reason (thought), nature (experience), and morality. Eventually Boorstin abandoned reason and morality, and relied upon nature (experience). See chapter four of The Terrors of Ideological Politics for a discussion of Morton's argument.

${ }^{2}$ The end of ideology argument was common during the 1950s. Daniel Bell's The End of Ideology (1960) was immensely important during this period. According to Rober Booth Fowler. intellectuals of this period saw ideology as a danger to American institutions (1978). For synoptic overviews of the 1950s and 1960s see Beck (1987), Fowler (1978), Matusow (1984), and Neuchterlein (1977).

${ }^{3}$ The standard view is that Boorstin represents the end of ideology perspective. This argument is found in Fowler $(1978,1991)$ and Higham (1959). This school contends that Boxrstin is opposed 
to political theory. "[Boorstin] affirmed what he felt was the American's special "genius," his loughminded ability to live without ideology and ultimate answers" (Fowler 1978. 51).

${ }^{4}$ For example, Diggins asserted that "[f]or Boorstin, man has no essence; he is what he becomes" (1971a, 103). Yet, such an assertion is possible only by ignoring the guiding influence of givenness. Givenness, Boorstin argues, comes directly from God (1953, 161). God's hand, therefore, is involved in the shaping of man, a point that Diggins does not address.

'There is a conflict between Boorstin's interpretation of the Revolution in The Genius of American Politics and in his subsequent work. The Americans: The National Experience. In The Genius of American Politics, Boorstin asserted that "1776 had no sequel. and needed none." The Revolution, in short. was completed in the eighteenth century, Boorstin suggests (1953, 74). Most revolutions. according to Boorstin, occur in stages. "In France, for example, 1789 was followed by 1830 and 1848 and 1870; a similar list could be made for Italy, Germany, and perhaps Russia" (Boxrstin 19.53, 74). Yet. in The Americans: The National Experience. Boorstin argued that "[t]he struggle for a new nation was not to be completed until 1865 or after" $(1965,404)$. This implies that the American Revolution did indeed have a sequel. This disjuncture between his earlier and later writings suggests that there may be yet another Daniel J. Boorstin; a Boorstin who has modified his views since the publication of The Genius of American Politics (which is, by all accounts, Boorstin's major work). Thus, this tension between the earlier and later Boorstins suggests another area for future research.

${ }^{6}$ Diggins has written that "[Hartz] found America imprisoned within an unseen and unfelt monolithic ideology" (Diggins 1988, 374). Boorstin's America is unchained by a God-inspired essence, not an ideology. In this respect, Boorstin's thought resembles Russell Kirk's argument in The Roots of American Order. Kirk contends that America owes much to the ancient Israelites, who entered into a Covenant with God. By agreeing to the Covenant, Kirk argues that man acquired an essence. The United States was founded on a moral code based on the ancient Jewish Covenant.

${ }^{7}$ I do not want to suggest that Boorstin is not a member of the so-called consensus school. However, I do want to argue that the unique nature of Boorstin's thought is obscured by such comprehensive categorizing. The third image clarifies the differences between Hartz and Boorstin. For a discussion of some of the issues related to "consensus" during the 1950s, see Beck (1987); Lutz (1992); Matusow (1984); Neuchterlein (1977); and Ricci (1984).

${ }^{8}$ In his book review of the Liberal Tradition, Boorstin was critical of Hartz's analysis; especially the notion that "irrational Lockeanism" had a grip on America (Boorstin 1955). Also see Paul Roazen's introduction to Louis Hartz's The Necessity of Choice (1990).

\section{REFERENCES}

Beck, Kent M. 1987. What Was Liberalism in the 1950s? Political Science Quarterly 102: 233-258. Beitzinger, A.J. nd. A History of American Political Thought. Charlottesville, VA: Ibis Publishing. Bell, Daniel. 1960. The End of Ideology: On the Exhaustion of Political Ideas in the Fifties. Cambridge: Harvard University Press.

Boorstin, Daniel J. 1953. The Genius of American Politics. Chicago and London: University of Chicago Press.

1955. Book review of The Liberal Tradition in America, by Louis Hartz. Commentary 20: $99-100$.

1960. America and the Image of Europe: Reflections on American Thought. New

York: Meridian Books.

1965. The Americans: The National Experience. New York: Random House. 1975. The Exploring Spirit: America and the World Experience. London: British Broadcasting Corporation.

1983. The Discoverers. New York: Random House. 
1992. The Crealors: A History of Heroes of the Imagination. New York: Random House.

Diggins, John Patrick. 1971a. Consciousness and ldeology in American History: The Burden of Daniel J. Boorstin. American Historical Review 76: 99-118.

1971b. The Perils of Naturalism: Some Reflections on Daniel J. Boorstin. American Charterly 28: 153-180.

1988. Knowledge and Sorrow: Louis Hartz's Quarrel with American History. Political Theory 16: 35.5-376.

Fowler. Robert Booth. 1978. Believing Skeptics: American Political Intellectuals, 1945-1964. Westport. CN: Greenwood Press.

1991. The Dance with Community: The Contemporary Debate in American Political Thought. Lawrence: University Press of Kansas.

Hartz. Louis. 1955. The Liberal Tradition in America: An Interpretation of American Political Thought Since the Revolution. New York: Harcourt.

Higham. John. 1959. The Cult of the 'American Consensus': Homogenizing Our Century. Commentary 27: 93-100.

Kirk, Russell. 1974. The Roots of American Order. LaSalle, IL: Open Court.

Lutz, Donald S. 1992. A Preface to American Political Theory. Lawrence: University Press of Kansas.

Matusow, Allen J. 1984. The Unraveling of America: A History of Liberalism in the 1960s. New York: Harper Collins.

Morton, Marian J. 1972. The Terrors of Ideological Politics: Liberal Historians in a Conservative Mood. Cleveland and London: The Press of Case Western Reserve University.

Neuchterlein, James A. 1977. Arthur M. Schlesinger, Jr., and the Discontents of Postwar American Liberalism. Review of Politics 39: 3-40.

Ricci, David M. 1984. The Tragedy of Political Science: Politics, Scholarship, and Democracy. New Haven and London: Yale University Press.

Roazen, Paul. 1990. Introduction to The Necessity of Choice: Nineteenth Century Political Thought. by Louis Hartz. New Brunswick and London: Transaction Publishers. 